\title{
Population structure of the pearly razorfish, Xyrichtys novacula (Actinopterygii: Labridae), in sand-seagrass mosaics: spatial variation according to habitat features and sampling techniques
}

\author{
Fernando Espino ${ }^{1}$, Raül Triay-Portella ${ }^{2}$, José Antonio González ${ }^{2}$, Ricardo Haroun ${ }^{1}$, \\ Fernando Tuya ${ }^{1}$ \\ ${ }^{1}$ Grupo de investigación en Biodiversidad y Conservación, Facultad de Ciencias del Mar, Universidad de Las Palmas de \\ Gran Canaria, Campus de Tafira, 35017 Las Palmas de Gran Canaria, Canary Islands, Spain. \\ E-mail: fesprod@gobiernodecanarias.org (FE), rharoun@dbio.ulpgc.es (RH), ftuya@yahoo.es (FT) \\ ${ }^{2}$ Grupo de investigación en Ecología Marina Aplicada y Pesquerías, Facultad de Ciencias del Mar, Universidad de Las \\ Palmas de Gran Canaria, Campus de Tafira, 35017 Las Palmas de Gran Canaria, Canary Islands, Spain. \\ E-mail: emap.raul@gmail.com (RTP), pepe.solea@ulpgc.es (JAG)
}

\begin{abstract}
Summary: Habitat structure affects the distribution of fishes, particularly across reef-dominated habitats, but few studies have connected patterns in the abundance of soft-bottom fishes with the structure of the habitat. The spatial and temporal patterns of variation in the abundance, biomass and population structure of the pearly razorfish, Xyrichtys novacula, inhabiting sand-Cymodocea nodosa seagrass mosaics were described through two complementary techniques: underwater visual counts and seine nets. We sought to analyse whether biotic (seagrass shoot density, leaf length and meadow cover) and abiotic (sediment composition and particle size) structural elements explained variation in patterns of abundance and biomass. Underwater visual counts registered a larger abundance of individuals and proved significant variation in fish abundance and biomass at the scale of locations, which was otherwise not detected through seine nets. Seasonal variation in fish abundance and biomass was, in all cases, minor. Habitat structural elements helped to explain patterns in fish abundance and biomass. This fish species was particularly abundant in sediments dominated by coarse sands in continuous meadows of $C$. nodosa (>90\% seagrass cover) with intermediate densities of 500 to 1000 shoots $\mathrm{m}^{-2}$, followed by large-sized seagrass patches with $>1000$ shoots $\mathrm{m}^{-2}$. A trade-off between protection provided by seagrass canopies and protection derived from its burial behaviour, limited under high seagrass shoot densities, may explain spatial variation patterns.
\end{abstract}

Keywords: habitat; structural complexity; soft bottoms; sediments; sex ratio.

Estructura poblacional del 'pejepeine', Xyrichtys novacula (Actinopterygii: Labridae), en mosaicos arena-pradera de fanerógama marina: variación espacial de acuerdo con las características del hábitat y técnicas de muestreo

Resumen: La estructura del hábitat afecta a la distribución de los peces, particularmente en los hábitats dominados por arrecifes. Sin embargo, los estudios que conectan patrones de abundancia de peces en fondos blandos con la estructura del hábitat son, comparativamente, más escasos. En este estudio, se describen los patrones espacio-temporales de variación en abundancia, biomasa y estructura poblacional del 'pejepeine', Xyrichtys novacula, en hábitats de arena y praderas de fanerógamas marinas constituidas por Cymodocea nodosa, empleando dos técnicas complementarias: censos visuales subacuáticos (UVCs) y arrastres (SNs). Se analizó si los elementos estructurales bióticos (densidad de pies, longitud de hoja y cobertura de la pradera) y abióticos (composición del sedimento y tamaño de las partículas) contribuyen a explicar la variación en los patrones de abundancia y biomasa. Los UVCs registraron una mayor abundancia de individuos y demostraron una variación significativa en abundancia y biomasa a escala de localidades, estas variaciones no fueron detectadas por los arrastres. La variación estacional en la abundancia y biomasa de individuos fue mínima en todos los casos. Los elementos estructurales del hábitat contribuyen a explicar los patrones de abundancia y biomasa de peces. Esta especie fue particularmente abundante en fondos dominados por arenas gruesas con praderas continuas de $C$. nodosa (cobertura $>90 \%$ ) con densidades de pies intermedias de $500<\mathrm{n}^{\circ}$ de pies $\mathrm{m}^{-2}<1000$, seguido por parches de fanerógamas de tamaño grande con densidades $>1000$ pies $\mathrm{m}^{-2}$. Un equilibrio entre la protección provista por la bóveda foliar y la protección derivada de su comportamiento de enterramiento, el cual está limitado por densidades de pies altas, puede explicar los patrones de variabilidad espacial de esta especie.

Palabras clave: hábitat; complejidad estructural; fondos blandos; sedimentos; sex ratio.

Citation/Como citar este artículo: Espino F., Triay-Portella R., González J.A., Haroun R., Tuya F. 2015. Population structure of the pearly razorfish, Xyrichtys novacula (Actinopterygii: Labridae), in sand-seagrass mosaics: spatial variation according to habitat features and sampling techniques. Sci. Mar. 79(2): 179-188. doi: http://dx.doi.org/10.3989/scimar.04219.05A

Editor: E. Macpherson.

Received: January 29, 2015. Accepted: April 21, 2015. Published: June 5, 2015.

Copyright: (C) 2015 CSIC. This is an open-access article distributed under the Creative Commons Attribution-Non Commercial Lisence (by-nc) Spain 3.0. 


\section{INTRODUCTION}

Habitat structure routinely affects the distribution and structure of nearshore fish assemblages (Gratwicke and Speight 2005, Tuya et al. 2011). A large body of literature has covered this research topic. Studies connecting patterns in the abundance of soft-bottom fishes with the structure of the habitat are, however, fewer in number. Soft bottoms are colonized by seagrass meadows, which largely increase the heterogeneity and complexity of the habitat relative to nearby unvegetated bottoms (Boström et al. 2006, Gullström et al. 2008, Hensgen et al. 2014). A large number of fish species inhabit both types of habitat, which are typically juxtaposed in mosaics within landscapes (Ferrell and Bell 1991, Gray et al. 1996, Horinouchi 2009). Different patterns in habitat use by nearshore fishes have been described there, including fish species that are more abundant in seagrass meadows, fish species more abundant on sand bottoms, and species with similar abundance in both types of habitat, even varying at different spatial and temporal scales (Ferrell and Bell 1991, Tuya et al. 2005, Horinouchi 2009). Providing insight into patterns of fish habitat use is particularly relevant for fish that are commercially exploited, which can be described in terms of varying patterns in abundance, biomass, size structure and sex ratio that are intrinsically linked with the specific peculiarities of the habitat.

The pearly razorfish, Xyrichtys novacula (Linnaeus, 1758) (Actinopterygii: Labridae), is a benthic, protogynous hermaphrodite (Bentivegna and Rasotto 1987) distributed in warm latitudes of the Atlantic Ocean, from North Carolina (USA) to Brazil, and from the southern Iberian Peninsula to Gabon, including the archipelagos of the Azores, Madeira, Canaries, Cape Verde and São Tomé as well as the Mediterranean Sea (Froese and Pauly 2015). In the Mediterranean region, this fish is a highly prized species, particularly in the Balearic Islands (Box et al. 2009, Alós et al. 2012), where it reaches top market prices (Beltrano et al. 2006). In the Canary Islands, however, captures of this fish are low, because it has never been a target for the local cuisine. In the Canarian small-scale fisheries, it is captured incidentally through hooks, fish-traps and trammel nets that target other fish species (Franquet and Brito 1995). Along its distributional range, several aspects of the biology and ecology of $X$. novacula have been previously studied, including reproduction (Bentivegna and Rasotto 1987, Marconato et al. 1995, Cardinale et al. 1998, Candi et al. 2004), juvenile morphology (Mercader 1991), age and growth patterns (Cardinale et al. 1998, Battaglia et al. 2010), trophic ecology (Cardinale et al. 1997, Castriota et al. 2005a,b, 2010, Beltrano et al. 2006), and habitat use (Katsanevakis 2005, Alós et al. 2012). This fish species often inhabits shallow waters (0-90 m depth, Fischer et al. 1987, Franquet and Brito 1995, Froese and Pauly 2015) on sandy bottoms (Mercader 1991, Brito et al. 2002, Katsanevakis 2005, Tuya et al. 2005, Alós et al. 2012), frequently adjacent to seagrass meadows and coral reefs (Schneider 1990). In turn, it may thrive in seagrass meadows (Fischer et al. 1987, Mercader 1991, Riera and Linde 2001, Castriota et al. 2005b, Box et al. 2009), particularly those dominated by the genera Cymodocea and Zostera (Brito et al. 2002, Castriota et al. 2005a, Tuya et al. 2005, Espino et al. 2011a,b), and less frequently in Posidonia beds (Beltrano et al. 2006, Box et al. 2010). However, there are no specific studies describing patterns of variation in the habitat use by this species in seagrass meadows, although some studies on seagrass fish assemblages, mainly in Cymodocea and Zostera, have been performed (Guidetti 2000, Guidetti and Bussotti 2002, Guidetti et al. 2002).

The goals of this study were two-fold. Firstly, we aimed to describe the spatial and temporal patterns of variation in the abundance, biomass and population structure (size structure and sex ratio) of this species inhabiting sand-seagrass mosaics through two complementary sampling techniques. Secondly, we sought to analyse whether biotic (seagrass shoot density, leaf length and meadow cover) and abiotic (sediment composition and particle size) structural elements of the habitat helped to explain variation in patterns of abundance and biomass of this species.

\section{MATERIALS AND METHODS}

\section{Study area}

Three locations dominated by seagrass meadows of Cymodocea nodosa (Ucria) Aschers. were selected at Gran Canaria Island (Fig. 1); two locations located on the southeast coast, $c a .2 \mathrm{~km}$ apart, and one located to the southwest of the island, ca. $50 \mathrm{~km}$ apart. There is no significant variation in oceanographic conditions (e.g. seawater temperature, salinity and chlorophyll $a$ concentrations) at the coast between the southeastern and southwestern side of the island (Tuya et al. 2014a), and the pool of fish species is the same on both sides of the island (Espino et al. 2011a). The oceanographic conditions are characterized by the northeastern trade winds and the Canary current, which flows towards the southwest. Sea surface temperature typically ranges from $18^{\circ} \mathrm{C}$ in winter to $24^{\circ} \mathrm{C}$ in summer (Navarro-Pérez and Barton 2001).

The area covered by these seagrass meadows ranges between 98417 and $261550 \mathrm{~m}^{2}$ at $10-18 \mathrm{~m}$ depth (Table 1, Tuya et al. 2014a). Each location was visited seasonally four times through an entire annual cycle: in February 2011, May 2011, August 2011 and November 2011. The dates were separated to encompass conditions encountered throughout an entire year. At each location, fish were sampled at two sites selected randomly, hundreds of metres apart.

\section{Fish sampling}

Pearly razorfish were sampled using two complementary sampling techniques: underwater visual censuses (hereafter UVCs) and seine nets (hereafter SNs). At each site, 12 replicated 25-m-long and 4-m-wide transects were firstly laid out randomly during daylight hours, 10:00-14:00 $\mathrm{h}$. Transects were carried out by the 


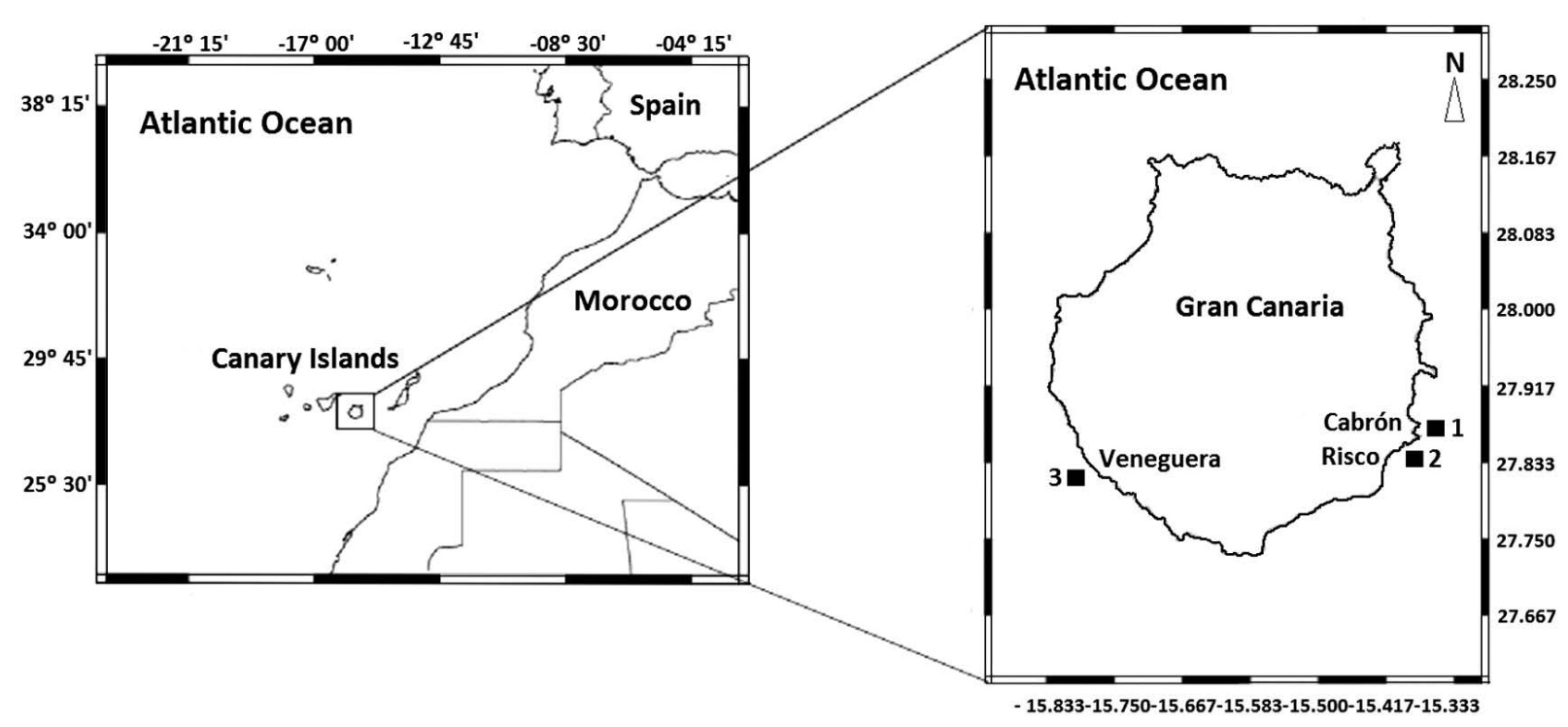

Fig. 1. - Map of the Canary Islands (northeastern Atlantic Ocean) showing the position of Gran Canaria Island and the three studied locations.

same two SCUBA divers (6 each diver) simultaneously, surveying different areas to avoid fish being counted twice. The abundance (total number of individuals) and size (to the nearest centimetre of total length) of all individuals of Xyrichtys novacula were recorded on waterproof forms. In the study area, this procedure provides optimal precision and accuracy to account for the abundance and size structure of both rocky-reef and seagrass fishes (Tuya et al. 2004, 2005, 2006, Espino et al. 2015). Biomasses of fish counted through UVCs were calculated using an unpublished length-weight relationship $\left(\mathrm{W}=0.0054 \mathrm{~L}^{3.3602}, \mathrm{R}^{2}=0.8576, \mathrm{n}=124\right)$.

Secondly, six replicated 25-m-long and 4-m-wide trawls were carried out using a seine net on approximately the same transect lines where the UVCs had been previously carried out. Distance between trawls varied between 20 and $30 \mathrm{~m}$. Hence, each trawl was considered as an independent replicate. This technique has been successfully applied in the study area, capturing small-sized fishes (Espino et al. 2011a,b, 2015). All fish captured by the SNs were preserved in a $10 \%$ formalin/seawater solution and carried to the laboratory, where the total length $(\mathrm{cm}, \mathrm{TL} \pm 0.1 \mathrm{~cm})$ and weight $(\mathrm{g}$, $\mathrm{W} \pm 0.001 \mathrm{~g}$ ) were recorded. For both sampling techniques, male and female fish were discriminated by the morphological criterion according to Oliver and Massutí (1952), Bentivegna and Rasotto (1987) and Mercader (1991).

\section{Structural elements of the habitat}

To test for predictive relationships between the physical structure of the habitat and the abundances and biomasses of Xyrichtys novacula, three biotic descriptors at each transect line were recorded: (1) shoot density (by counting seagrass shoots in six $25 \times 25 \mathrm{~cm}$ quadrats that were deployed in the middle of each transect line), (2) leaf length (by measuring the average leaf length in 20 shoots selected randomly within each quadrat), and (3) seagrass cover during UVC performance (by registering the distance under a $1 \mathrm{~cm} \times 25 \mathrm{~m}$ flexible line transect covered by the seagrass Cymodocea nodosa to the nearest centimetre and subsequent calculation of \% cover, $\mathrm{n}=12$ ) (Barberá et al. 2005, Espino et al. 2011a, 2015) (Table 1).The sediment characteristics, i.e. percentages of gravel, sand, silt, and mean diameter of particles $\left(D_{50}\right)$, for each site within each location $(n=3)$ were obtained from the Ecocartographic Study of the South Coast of Gran Canaria Island (Ministerio de Medio Ambiente 2002) (Table 1).

\section{Statistical analysis}

The abundance and biomass of the razorfish were partitioned by means of three-way ANOVAs that tested for differences between times (seasons), locations, and sites within locations. The model incorporated the

Table 1. - Physical structure of the three locations dominated by Cymodocea nodosa seagrass meadows. Surface $\left(\mathrm{m}^{2}\right)$, depth ranges $(\mathrm{m})$ and meadow type are provided for each location. Density (number of shoots $\mathrm{m}^{-2}$; mean \pm standard error), leaf length (cm; mean \pm se), cover (\%; mean \pm se), gravel $(\%)$, sand $(\%)$, silt $(\%)$, and mean diameter of particles $\left(\mathrm{D}_{50}, \mathrm{~mm}\right)$ are also provided for each site within each location.

\begin{tabular}{|c|c|c|c|c|c|c|c|c|c|c|}
\hline & Surface & Depth & Type & Density* & Leaf length & Cover & Gravel & Sand & Silt & $\mathrm{D}_{50}$ \\
\hline Cabrón 1 & & & & $699.31 \pm 24.97$ & $26.71 \pm 0.96$ & $92.81 \pm 1.25$ & 19.06 & 79.04 & 1.90 & 0.48 \\
\hline Cabrón 2 & 101638 & $10-18$ & continuous & $580.75 \pm 17.47$ & $24.91 \pm 0.98$ & $99.48 \pm 0.53$ & 3.62 & 95.77 & 0.61 & 0.37 \\
\hline Risco 1 & & & & $1183.06 \pm 42.64$ & $22.58 \pm 0.86$ & $94.67 \pm 1.42$ & 3.17 & 94.73 & 2.10 & 0.38 \\
\hline Risco 2 & 261550 & $10-17$ & patchy & $1388.46 \pm 49.91$ & $21.94 \pm 0.89$ & $91.14 \pm 1.64$ & 4.82 & 93.21 & 1.97 & 0.40 \\
\hline Veneguera 1 & & & & $425.27 \pm 16.91$ & $31.08 \pm 1.01$ & $61.98 \pm 1.09$ & 0.02 & 89.43 & 10.55 & 0.13 \\
\hline Veneguera 2 & 98417 & $10-15$ & patchy & $425.12 \pm 16.64$ & $32.05 \pm 1.46$ & $63.75 \pm 1.79$ & 0.02 & 94.28 & 5.70 & 0.16 \\
\hline
\end{tabular}

* Classification of $C$. nodosa seagrass meadows of the Canary Islands by density $(\mathrm{d})$ : Low $=\mathrm{d}<500 ; \mathrm{Medium}=500<\mathrm{d}<1000$;

High $=1000<\mathrm{d}<1500$; Very high $=\mathrm{d}>1500$ (density in number of shoots $\mathrm{m}^{-2}, \mathrm{n}=100$, Espino 2004). 
Table 2. - Results of the analysis of variance (ANOVA) testing the effects of 'Time' (a fixed factor), 'Location' (a random factor, orthogonal to the previous factor), and 'Site' (a random factor nested within 'Time' and 'Location') on the abundance and biomass of the pearly razorfish, Xyrichtys novacula, recorded through UVCs.

\begin{tabular}{|c|c|c|c|c|c|c|c|}
\hline \multirow[t]{2}{*}{ Source of variation } & \multirow[b]{2}{*}{ DF } & \multicolumn{3}{|c|}{ Abundance } & \multicolumn{3}{|c|}{ Biomass } \\
\hline & & MS & $\mathrm{F}$ & $\mathrm{p}$ & MS & $\mathrm{F}$ & $\mathrm{p}$ \\
\hline Time, $\mathrm{T}$ & 3 & 2.7456 & 0.5224 & 0.7002 & 111.4267 & 0.5552 & 0.7226 \\
\hline Location, L & 2 & 38.8899 & 7.3995 & 0.0096 & 1283.4646 & 6.3945 & 0.0078 \\
\hline Site $(\mathrm{T} \times \mathrm{L}), \mathrm{Si}$ & 12 & 5.2558 & 8.3108 & 0.0002 & 200.7145 & 8.7714 & 0.0002 \\
\hline $\mathrm{T} \times \mathrm{L}$ & 6 & 2.2537 & 0.4288 & 0.8800 & 117.7673 & 0.5867 & 0.8034 \\
\hline Residual & 264 & 0.6324 & & & 22.8827 & & \\
\hline
\end{tabular}

factors (1) 'Time' (a fixed factor with four levels, i.e. the four seasons); (2) 'Location' (a random factor with three levels and orthogonal to 'Time'); and (3) 'Site' (a random factor with two levels nested within 'Location' and 'Time'). In particular, analyses focused on the effects of 'Time' and its interaction term with 'Location' (' $\mathrm{T} \times \mathrm{L}$ '). Prior to the analyses, the Cochran test was used to check for homogeneity of variances. All types of transformation of UVC data were tried to achieve homogeneous variances. However, data from UVCs did not achieve homogenous variances for fish abundance $(\mathrm{C}=0.3654, \mathrm{p}<0.01)$ and biomass $(\mathrm{C}=0.1376, \mathrm{p}<0.01)$. In this case, the significance level was set at 0.01 instead of the 0.05 , to decrease a type I error; ANOVA is robust to heterogeneous variances for large, balanced experiments (Underwood 1997). Data from SNs were $\mathrm{Ln}(\mathrm{x}+1)$-transformed and rendered homogenous variances for fish abundance and biomass (Cochran tests, $\mathrm{C}=0.1044, \mathrm{C}=0.1396, \mathrm{p}>0.05$, respectively). The sex ratio was estimated overall and separately for data provided by each sampling technique. A chi-square tested the null hypothesis of equality of frequencies between sexes (i.e. a 1:1 ratio) with a significance level of $5 \%$ $(\alpha=0.05)$ (Sachs 1982, Sokal and Rohlf 2012). A linear regression model was fitted to pairwise abundances and biomasses obtained by each sampling protocol at each site and season $(n=24)$ to test for a predictive relationship between them. Multiple linear regression, using the DistLM routine via 999 permutations of the data (Anderson 2001), tested the significance of the relationships between the set of predictor variables, i.e. density of shoots, leaf length, seagrass cover, percentages of gravel, sand and silt, and mean diameter of particles $\left(\mathrm{D}_{50}\right)$, and the total abundance and biomass of the razorfish (untransformed data). The 'Forward' selection procedure and the AIC selection criterion were applied to select the models with the largest parsimony.

\section{RESULTS}

\section{Underwater visual censuses}

A total of 443 individuals were counted, from a minimum of 0 to a maximum of 34 ind./100 $\mathrm{m}^{2}$. Significant differences in abundances were detected between locations (ANOVA test, L, $\mathrm{p}<0.01$, Table 2, Fig. 2A), which were otherwise consistent through time (ANOVA test, T, $\mathrm{p}>0.01$, 'T $\times \mathrm{L}$ ', $\mathrm{p}>0.01$, Table 2, Fig. 2A). Similarly, fish biomass differed between locations (ANOVA test, L, p $<0.01$, Table 2, Fig. 2B) with no temporal effects (ANOVA test, $\mathrm{T}, \mathrm{p}>0.01$, ' $\mathrm{T} \times \mathrm{L}$ ', $p>0.01$, Table 2, Fig. 2B). Males $(n=156)$ ranged from
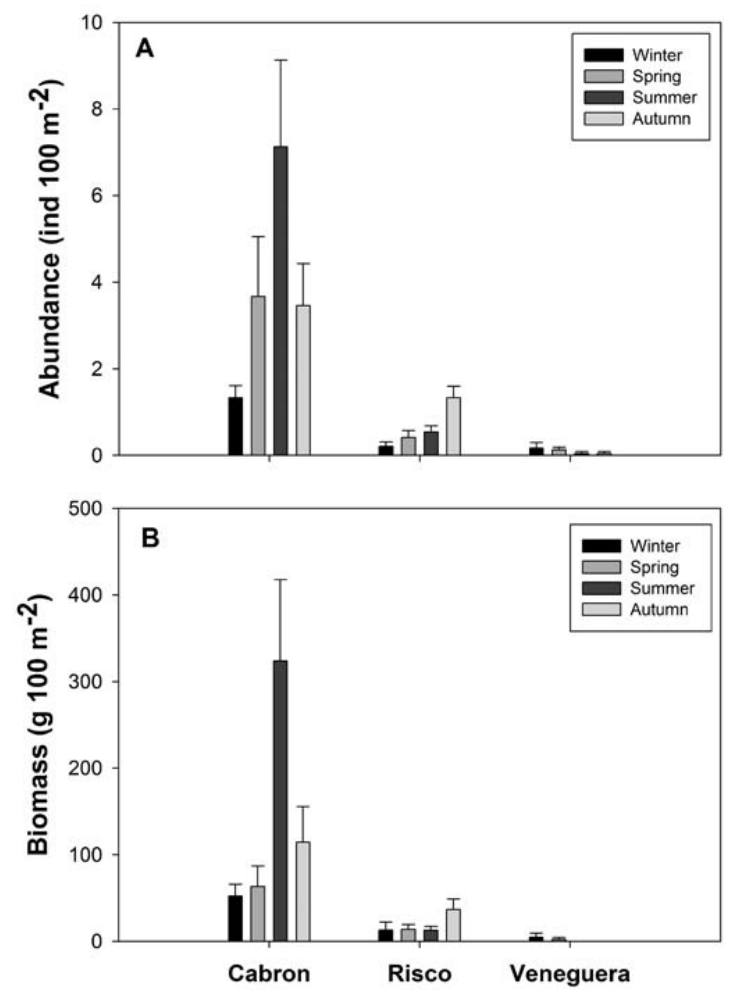

Fig. 2. - Mean abundance (A) and mean biomass (B) of the pearly razorfish, Xyrichtys novacula, at each location and time, recorded through the UVCs. Error bars indicate standard error of the means.

13.0 to $20.0 \mathrm{~cm}$ TL, while females $(\mathrm{n}=287)$ ranged from 3.0 to $15.0 \mathrm{~cm}$ TL (Fig. 3A); males $(16.2 \pm 2.0$ $\mathrm{cm}$, mean $\pm \mathrm{se})$ were larger than females $(10.4 \pm 2.5 \mathrm{~cm})$ $(\mathrm{t}$-test, $\mathrm{t}=24.46, \mathrm{p}<0.001)$. Females were significantly more abundant than males, in a male:female proportion of $1: 1.85\left(\chi^{2}=40.11, \mathrm{p}<0.001\right)$.

The multiple regression model explained $c a .30 \%$ of the variability of fish abundance. The percentage of silt, seagrass shoot density and leaf length were the predictor variables that most contributed to explaining variability in fish abundance (Table 3A, Fig. 4A-C). For fish biomass, the model accounted for $\mathrm{ca}$. $32 \%$ of the total variability. The variables that most contributed to explaining variability in fish biomass were seagrass cover, seagrass shoot density and percentage of sand (Table 3B, Fig. 4D-F).

\section{Seine nets}

A total of 124 individuals (2524.28 $\mathrm{g}$ of fish) were collected, from a minimum of 0 to a maximum of 10 ind./100 $\mathrm{m}^{2}$. No significant differences in fish abun- 


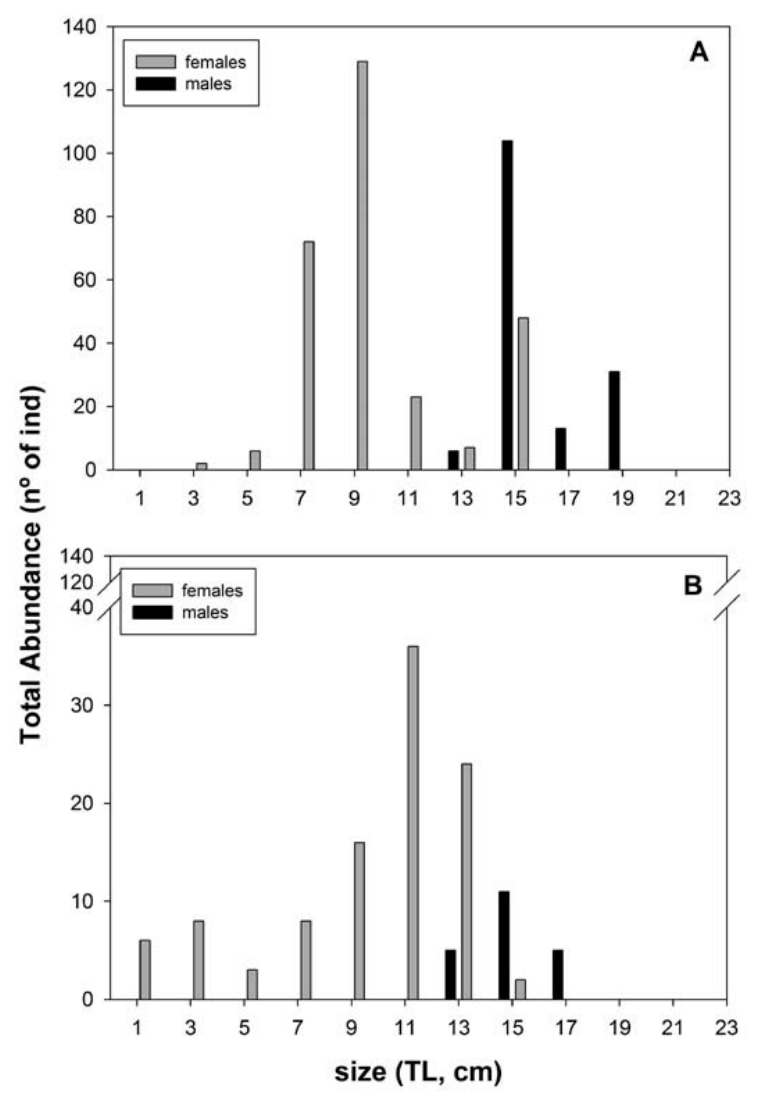

Fig. 3. - Total number of individuals of the pearly razorfish, $X y$ richtys novacula, for each size class and sex recorded through UVCs (A) and SNs (B).
Table 3. - Results of the multiple regressions tests (sequential tests) testing for significant relationships between predictor variables and the (A) abundance and (B) biomass of the pearly razorfish, Xyrichtys novacula, recorded through the UVCs.

\begin{tabular}{lcc}
\hline & $\mathrm{p}$ & $\begin{array}{c}\text { Proportion of variation } \\
\text { explained }\end{array}$ \\
\hline (A) Abundance & & \\
$\%$ silt & 0.001 & 0.0882420 \\
Shoot density & 0.003 & 0.0395270 \\
Leaf length & 0.001 & 0.0478960 \\
\% sand & 0.001 & 0.0497160 \\
D $_{50}$ & 0.001 & 0.0736480 \\
Seagrass cover & 0.154 & 0.0051211 \\
(B) Biomass & & \\
Seagrass cover & 0.001 & 0.152170 \\
Shoot density & 0.001 & 0.031080 \\
\% sand & 0.001 & 0.034937 \\
D & 0.004 & 0.030101 \\
Leaf length & 0.001 & 0.061564 \\
\% silt & 0.022 & 0.013166 \\
\hline
\end{tabular}

dances and biomass were detected between locations (ANOVA test, L, p>0.05, Table 4, Fig. 5A and 5B, respectively) and times (ANOVA test, $\mathrm{T}, \mathrm{p}>0.05$, 'T $\times$ L', $p>0.05$, Table 4, Fig. 5A and 5B, respectively). Males $(\mathrm{n}=21)$ ranged from 12.9 to $17.2 \mathrm{~cm}$ TL, while females $(\mathrm{n}=103)$ ranged from 1.2 to $14.5 \mathrm{~cm}$ TL (Fig. 3B); males $(19.52 \pm 3.45 \mathrm{~cm})$ were larger than females $(15.0 \pm 1.3 \mathrm{~cm}) \quad(\mathrm{t}-\mathrm{test}, \mathrm{t}=12.36, \mathrm{p}<0.001)$. Females were significantly more abundant than males, in a male:female proportion of $1: 4.9\left(\chi^{2}=54.23, \mathrm{p}<0.001\right)$.

The multiple regression models explained $c a .16 \%$ and $26 \%$ of the total variability in fish abundance and biomass, respectively (Table 5). The percentage of silt, sand, and seagrass cover were the predictor variables that most contributed to explaining variation in abun-
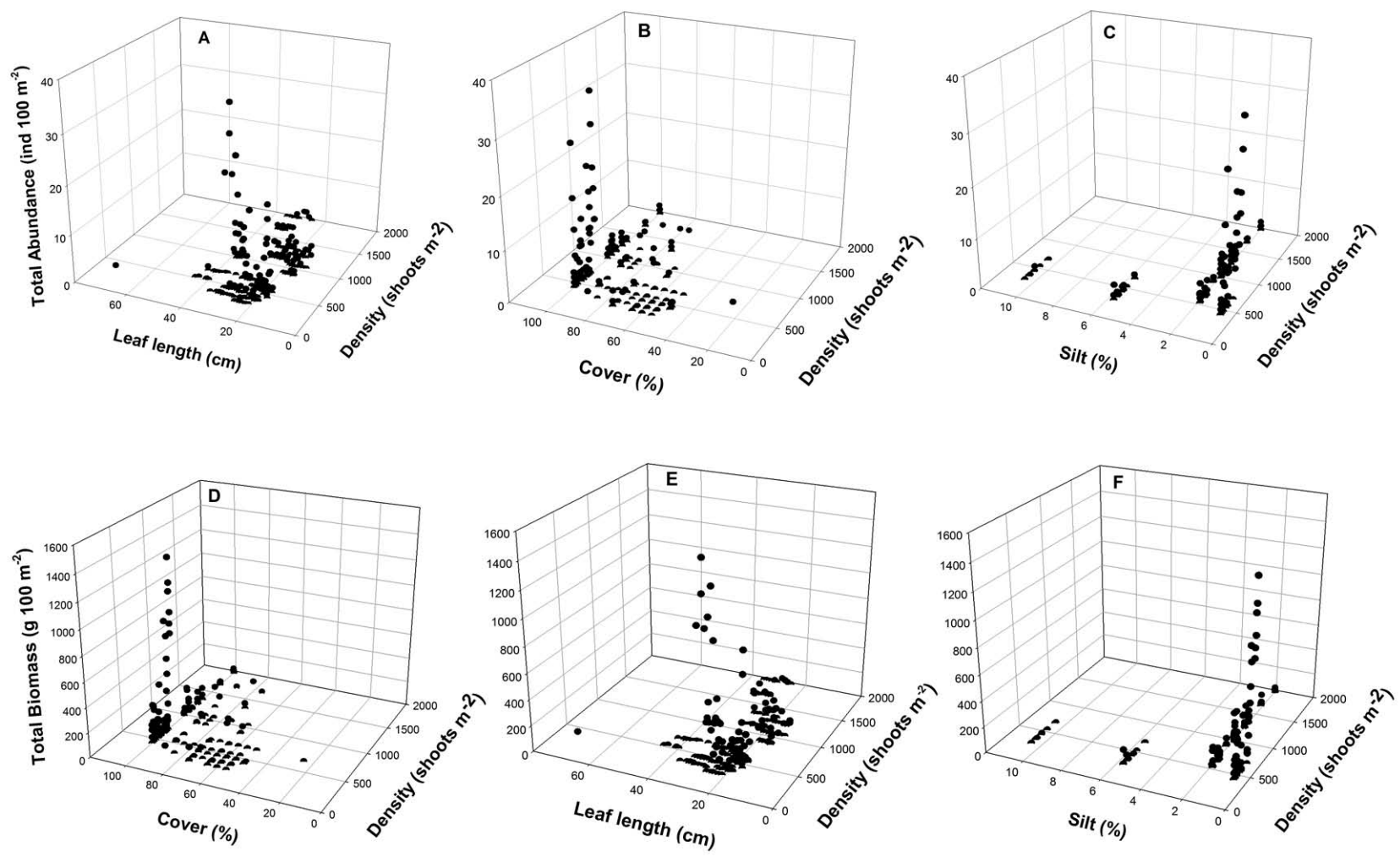

Fig. 4. - Relationships between total abundance (A-C) and biomass (D-F) of the pearly razorfish, Xyrichtys novacula, recorded through UVCs, and the structural elements of the habitat. 
$184 \cdot$ F. Espino et al.

Table 4. - Results of the analysis of variance (ANOVA) testing the effects of 'Time' (a fixed factor), 'Location' (a random factor, orthogonal to the previous factor), and 'Site' (a random factor nested within 'Time' and 'Location') on the abundance and biomass of the pearly razorfish, Xyrichtys novacula, recorded through SNs.

\begin{tabular}{|c|c|c|c|c|c|c|c|}
\hline \multirow[t]{2}{*}{ Source of variation } & \multirow[b]{2}{*}{$\mathrm{DF}$} & \multicolumn{3}{|c|}{ Abundance } & \multicolumn{3}{|c|}{ Biomass } \\
\hline & & MS & $\mathrm{F}$ & $\mathrm{p}$ & MS & $\mathrm{F}$ & $\mathrm{p}$ \\
\hline Time, $\mathrm{T}$ & 3 & 0.3694 & 0.1954 & 0.8960 & 12.19730 & 0.2959 & 0.8274 \\
\hline Location, L & 2 & 4.8397 & 2.5594 & 0.1204 & 158.5654 & 3.8469 & 0.0474 \\
\hline Site $(\mathrm{T} \times \mathrm{L}), \mathrm{Si}$ & 12 & 1.8909 & 5.0587 & 0.0002 & 41.21900 & 5.3237 & 0.0002 \\
\hline $\mathrm{T} \times \mathrm{L}$ & 6 & 0.4170 & 0.2205 & 0.9634 & 7.406100 & 0.1797 & 0.9782 \\
\hline Residual & 120 & 0.3738 & & & 7.742500 & & \\
\hline
\end{tabular}
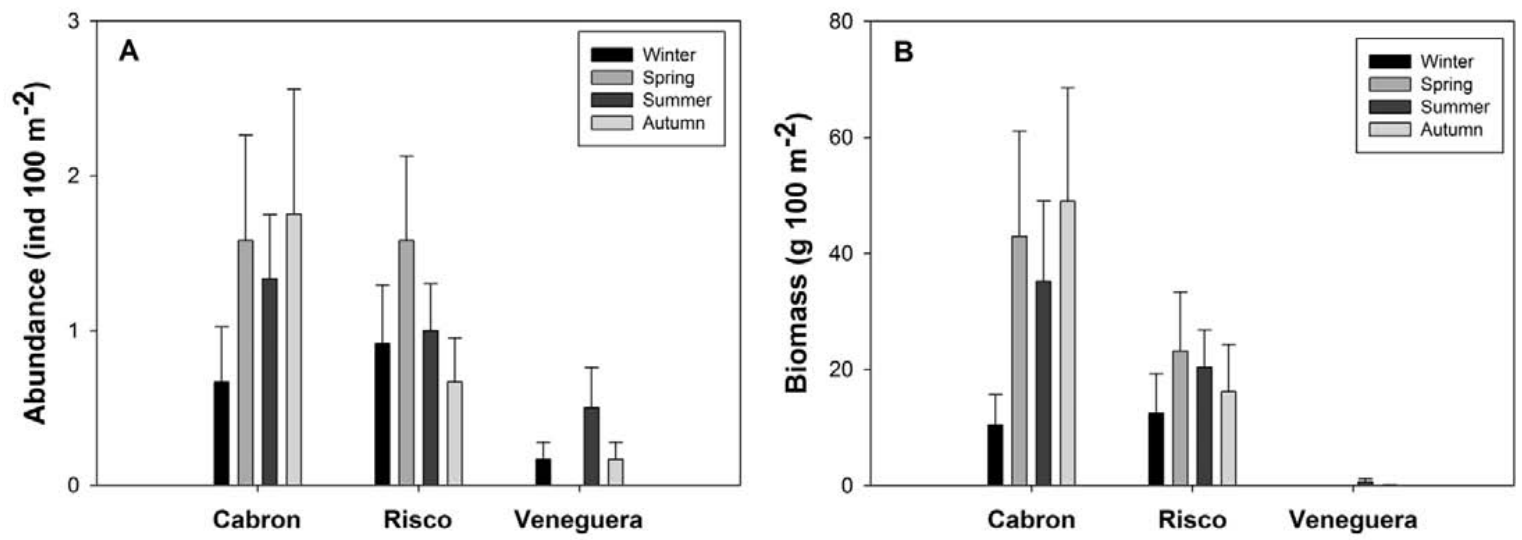

Fig. 5. - Mean abundance (A) and mean biomass (B) of the pearly razorfish, Xyrichtys novacula, at each location and time, recorded through the SNs. Error bars indicate standard error of the means.
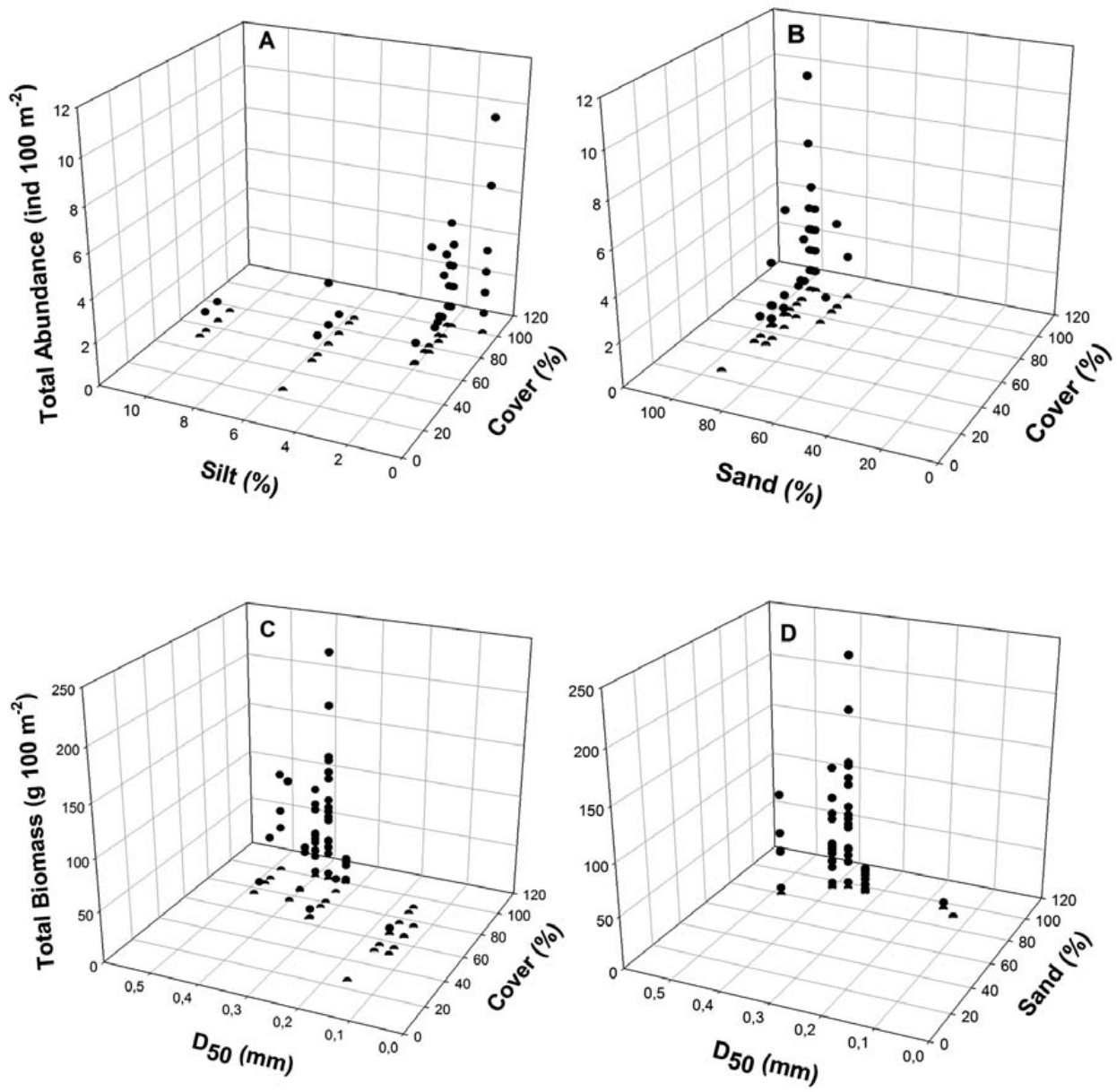

Fig. 6. - Relationships between total abundance (A-B) and biomass (C-D) of the pearly razorfish, Xyrichtys novacula, recorded through SNs, and the structural elements of the habitat. 
Table 5. - Results of the univariate multiple regressions tests (sequential test) testing for significant relationships between predictor variables and the total (A) abundance and (B) biomass of the pearly razorfish, Xyrichtys novacula, recorded through the SNs.

\begin{tabular}{lcc}
\hline & $\mathrm{p}$ & $\begin{array}{c}\text { Proportion of variation } \\
\text { explained }\end{array}$ \\
\hline (A) Abundance & & \\
$\%$ silt & 0.001 & 0.106960 \\
\% sand & 0.017 & 0.037475 \\
$\quad$ Seagrass cover & 0.097 & 0.018267 \\
(B) Biomass & & \\
$\quad$ Seagrass cover & 0.001 & 0.184240 \\
$\quad \%$ sand & 0.006 & 0.047895 \\
$\mathrm{D}_{50}$ & 0.018 & 0.032192 \\
\hline
\end{tabular}

dance (Table 5A, Fig. 6A-B). Seagrass cover, percentage of sand and the $D_{50}$ were the variables that most contributed to explaining variability in fish biomass (Table 5B, Fig. 6C-D).

\section{Comparison between sampling techniques}

The sex ratio derived from both sampling methods differed significantly $\left(\chi^{2}=17.94, \mathrm{p}<0.001\right)$; females were more abundant in SNs than in UVCs. Though UVCs recorded a larger abundance of individuals, there was a significant predictive relationship between abundances and biomasses detected through the two sampling methods (Fig. 7A-B).
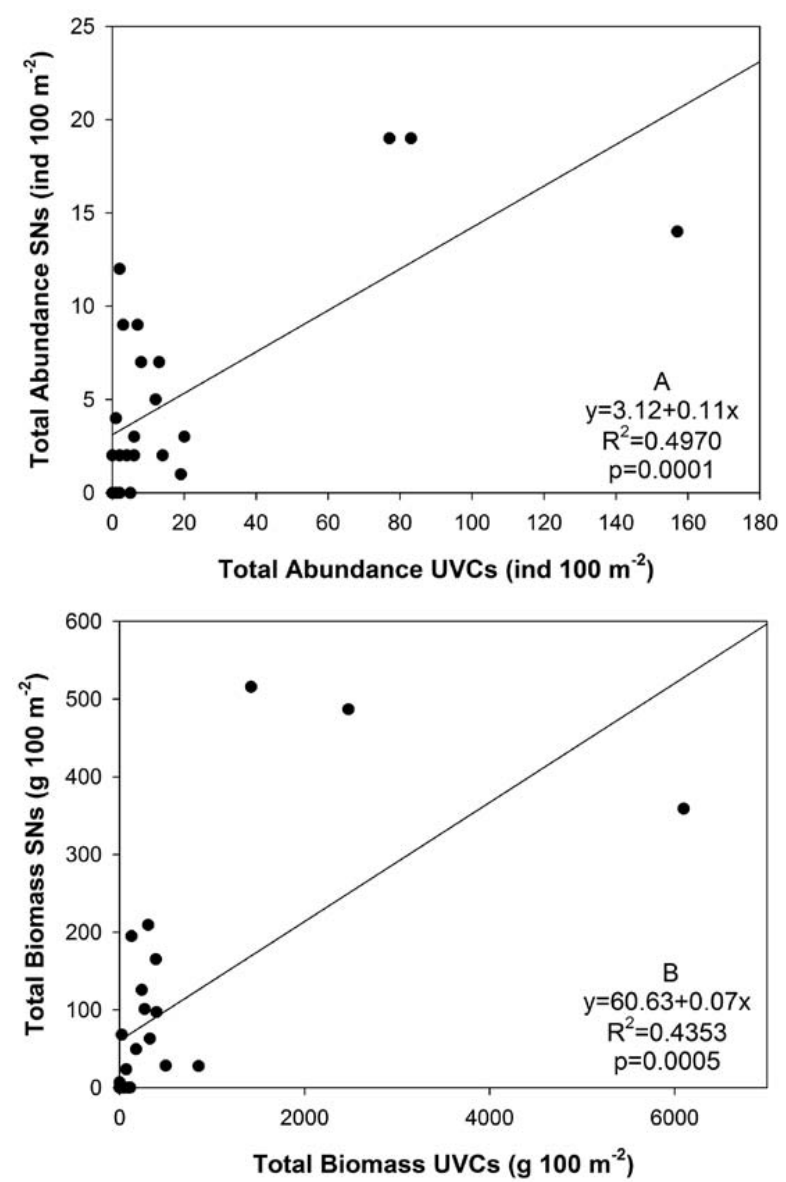

Fig. 7. - Relationships between the total abundances (A) and total biomasses (B) of the pearly razorfish, Xyrichtys novacula, recorded through UVCs and SNs.

\section{DISCUSSION}

In the study region, Xyrichtys novacula is found on unvegetated sandy bottoms and seagrass meadows of C. nodosa (Brito et al. 2002, Tuya et al. 2005, Espino et al. 2011a,b). The lack of temporality for the abundance and biomass patterns of this species suggests that individuals remain stable through seasons and that this species has a strong affinity for sandseagrass mosaics (Tuya et al. 2005, Box et al. 2009). In a similar way, Katsanevakis (2005) pointed out a lack of seasonal effects on densities of $X$. novacula from the eastern Mediterranean Sea. Individuals of this species typically display a reduced 'home range' $\left(<0.5 \mathrm{~km}^{2}\right)$, with a small habitat use area, i.e. a sedentary life style (Alós et al. 2012). This has been explained, at least during the reproductive period, by the complex social structure of $X$. novacula, a polygynous species with harem behaviour, where females occupy small territories and males patrol and defend (from other males) larger areas usually encompassing four to six female territories (Marconato et al. 1995). This territorial behaviour somehow explains the temporal stability in the patterns of abundance and biomass of this species in sand-seagrass mosaics. The results of this study do not support the hypothesis suggested in the Mediterranean Sea that, during the cold season, the species spends most of the time buried in the sand (Oliver and Massutí 1952, Cardinale et al. 1998) or migrates to deep waters (Oliver and Massutí 1952, Candi et al. 2004).

In contrast, the abundance and biomass of $X$. novacula varied at the spatial scales of locations and sites within locations. This means that variation in razorfish abundance and biomass was mostly determined by variation in seagrass structural attributes operating at the scale of locations and sites within locations. This species has a specific relation with the substrate, as it buries in the sediment under any sign of alarm (i.e. a predator). Moreover, this species bury into burrows during the night-time, therefore displaying a clear daily rhythm of activity (Lieske and Myers 1994, Alós et al. 2012). Hence, differences in habitat structure between locations may help to explain differences in fish abundance and biomass at this scale. Our data suggest that this fish was most abundant in continuous meadows ( $>90 \%$ seagrass cover) with intermediate densities of 500 to 1000 shoots $\mathrm{m}^{-2}$ (see Table 1). This was particularly the case at the location 'Cabrón', where abundances reached up to 34 ind. $/ 100 \mathrm{~m}^{2}$. Here, fish may bury into burrows between the complex matrix of seagrass rhizomes ( $\mathrm{F}$. Espino and F. Tuya, pers. obs.), because seagrass shoot density does not exceed large values, i.e. 1000 shoots $\mathrm{m}^{-2}$, which may impede the burial behaviour of this species, e.g. large above-ground stocks usually occur with high below-ground biomass, which might reduce the penetrability of infauna into the sediment (Peterson 1982, Goshima and Peterson 2012, González-Ortiz et al. 2014). Large-sized seagrass patches with shoot densities $>1000$ shoots $\mathrm{m}^{-2}$ surrounded by sand corridors, e.g. the location 'Risco', may also provide a suitable habitat (Espino et al. 2011b). A large seagrass shoot density may limit the capacity of fish to dig into the 
sediment. However, individuals may rapidly disperse towards adjacent sandy corridors to bury and so avoid predation. The sibling species Xyrichtys splendens Castelnau, 1855, distributed in the Caribbean Sea, also inhabits shallow sandy bottoms and seagrass meadows. Though seagrass canopies provide protection against predators, the capacity to bury into the substrate is here limited in comparison with unvegetated bottoms. In fact, the green razorfish modifies its sand-diving behaviour in seagrass habitats (Nemtzov 1994). As a result, a trade-off between protection provided by seagrass canopies and protection derived from burial behaviour may explain the spatial variability of this fish species.

The regression models showed that the average seagrass leaf length affected the distribution of Xyrichtys novacula; a larger leaf length may increase the capacity of protection by the habitat, as has been reported for many fishes in seagrass meadows (Gullström et al. 2008, Hori et al. 2009). The type of sediment (i.e. the dominant particle size) was another important driver of the abundance and biomass patterns of X. novacula in the study region. In the Mediterranean Sea, the distribution of this species seems to rely on specific sediment features; the largest abundances were found in sediments dominated by coarse and very coarse sands (Katsanevakis 2005). Though the location 'Veneguera' has a low shoot density $\left(<500\right.$ shoots $\left.\mathrm{m}^{-2}\right)$ and seagrass cover $(\sim 63 \%)$, fish abundance and biomass were low. This may be explained by the specific features of the sediment, including a larger amount of fine sediments in comparison with the other locations (8.125 vs 1.25 $2.03 \%)$ : i.e. the $\mathrm{D}_{50}$ was lower here than at the other two locations $(0.14$ vs $0.42-0.39 \mathrm{~mm})$. This would complicate the capacity of individuals to construct burrows and to bury and dive into the substrate. This result fits with findings from the Mediterranean Sea, where the finer the sediment the less abundant is X. novacula (Katsanevakis 2005); specifically, particle grain sizes between 0.125 and $0.250 \mathrm{~mm}$ are not suitable for this species (Alós et al. 2012).

Another element, not considered here, that may shed light to unravel patterns in abundance and biomass of $X$. novacula is the availability of feeding resources. This species is zoo-benthivorous, mainly consuming crustaceans, molluscs and echinoderms that inhabit bottoms dominated by well-sorted sands and coarse sands (Cardinale et al. 1997, Castriota et al. 2005a, Beltrano et al. 2006). Soft bottoms colonized by C. nodosa offer a rich fauna of endo-, epi- and suprabenthic organisms (Tuya et al. 2001, 2014b, Herrera et al. 2014), which are a potential feeding resource for juvenile and adult fish (Castriota et al. 2005b). In the Mediterranean Sea, trophic studies have revealed that the pearly razorfish is a euryphagic species that feeds on trophic resources available in each environment (Cardinale et al. 1997) and the total prey abundance may affect the abundance of razorfish but not the abundance of specific prey species (Katsanevakis 2005). As a result, the presence of these meadows may provide an ecological advantage for $X$. novacula, since individuals may consume prey inhabiting sandy bottoms, as well as those directly associated with seagrass meadows (Castriota et al. 2005b).

Seagrass meadows of Cymodocea nodosa may be a suitable habitat not only for adult fish but also for juveniles, as our data have demonstrated (18.28\% and $33.06 \%$ of juvenile razorfish recorded by UVCs and SNs, respectively). The range of sizes obtained by each type of sampling technique influenced the sex ratio. Still, females dominated numerically in both cases, particularly in the data obtained through the SNs. This can be explained, firstly, by a higher selectivity for small sizes (0.5-10.0 cm TL) of SNs, i.e. a larger capturability for small-sized individuals (females in our case study); this has also been observed in previous studies in the study area (Espino et al. 2011a,b). In contrast, large-sized individuals (typically males, TL $>17$ $\mathrm{cm}$ ) tend to escape from the sampling gear. For UVCs, however, small-sized individuals $(\mathrm{TL}<3.0 \mathrm{~cm})$ are difficult to detect, while large-sized individuals (TL $>17$ $\mathrm{cm}$ ) are often easier to spot (Franco et al. 2012, Tuya et al. 2014b, Espino et al. 2015). In our study, UVCs recorded a larger abundance of individuals; for mature populations of this species, the sex ratio rendered by UVCs seems to provide a good approximation to the structure of the population. Our study detected a significant correlation between data supplied by the UVCs and the trawls. However, it is worth noting that the significance of this relationship was mostly driven by large abundances and biomasses at three sites. As a result, this finding should be taken with caution.

In summary, the pearly razorfish, Xyrichtys novacula, shows spatial variation in abundances and biomasses that seem to be connected with variation in habitat structural elements, with effects independent of temporality. A balance between protection provided by seagrass canopies and protection provided by its burial behaviour seems to clarify the spatial variability of this fish species.

\section{ACKNOWLEDGEMENTS}

Financial support was received from the Government of the Canary Islands and the EU ERDF within the framework of the PCT MAC 2007-2013 project GESMAR (MAC/2/C068), in close liaison with the insular administration of Cabildo de Gran Canaria. We would like to thank P. Martínez-Corbalán and M. Farray for their collaboration at the Cabildo de Gran Canaria. L. Ortega, A. Ulibarri, H. Hernández-Zerpa and T. Sánchez assisted during the collection of field data. F. Tuya was supported by the MINECO 'Ramón y Cajal' programme and R. Haroun was partially supported by the Campus Atlántico Tricontinental.

\section{REFERENCES}

Alós J., Cabanellas-Reboredo M., Lowerre-Barbieri S. 2012. Diel behaviour and habitat utilisation by the pearly razorfish during the spawning season. Mar. Ecol. Prog. Ser. 460: 207-220. http://dx.doi.org/10.3354/meps09755

Anderson M.J. 2001. Permutation tests for univariate or multivariate analysis of variance and regression. Can. J. Fish. Aquat. Sci. 58: 626-639.

http://dx.doi.org/10.1139/f01-004 
Barberá C., Tuya F., Boyra A., et al. 2005. Spatial variation in the structural parameters of Cymodocea nodosa seagrass meadows in the Canary Islands. Bot. Mar. 48: 122-126. http://dx.doi.org/10.1515/BOT.2005.021

Battaglia P., Castriota L., Consoli P., et al. 2010. Age and growth of pearly razorfish, Xyrichtys novacula (Linnaeus 1758), in the central Mediterranean Sea. J. Appl. Ichthyol. 26: 410-415. http://dx.doi.org/10.1111/j.1439-0426.2009.01383.x

Beltrano A.M., Cannizzaro L., Vitale S., et al. 2006. Preliminary study on the feeding habits of cleaver wrasse Xyrichthys novacula (Pisces: Labridae) in the Strait of Sicily (Mediterranean Sea). Electron. J. Ichthyol. 2: 50-54.

Bentivegna F., Rasotto M.B. 1987. Protogynous hermaphroditism in Xyrichthys novacula (L. 1758). Cybium 11: 75-78

Boström C., Jackson E.L., Simenstad C.A. 2006. Seagrass landscapes and their effects on associated fauna: A review. Estuar. Coast. Shelf Sci. 68: 383-403 http://dx.doi.org/10.1016/j.ecss.2006.01.026

Box A., Grau A.M., Blanco A., et al. 2009. Els raors (Xyrichthys novacula) a la Reserva dels Freus d'Eivissa i Formentera; efecte de la protecció espacial. Boll. Soc. Hist. Nat. Illes Balears 52: 193-201.

Box A., Deudero S., Blanco A., et al. 2010. Differences in $\delta 13 \mathrm{C}$ and $\delta 15 \mathrm{~N}$ stable isotopes in the pearly razorfish Xyrichtys novacula related to the sex, location and spawning period. J. Fish Biol. 76: $2370-2381$. http://dx.doi.org/10.1111/j.1095-8649.2010.02627.x

Brito A., Pascual P.J., Falcón J.M., et al. 2002. Peces de las Islas Canarias. Catálogo comentado e ilustrado. Francisco Lemus Editor, La Laguna, 419 pp.

Candi G., Castriota L., Andaloro F., et al. 2004. Reproductive cycle and sex inversion in razor fish, a protogynous labrid in the southern Mediterranean Sea. J. Fish Biol. 64: 1498-1513. http://dx.doi.org/10.1111/j.0022-1112.2004.0404.x

Cardinale M., Colloca F., Ardizzone G.D. 1997. Feeding ecology of Mediterranean razorfish Xyrichthys novacula in the Tyrrhenian Sea (central Mediterranean Sea). J. Appl. Ichthyol. 13: 105-111. http://dx.doi.org/10.1111/j.1439-0426.1997.tb00109.x

Cardinale M., Colloca F., Ardizzone G.D. 1998. Growth and reproduction of Xyrichthys novacula (Pisces: Labridae) in the Mediterranean Sea. Sci. Mar. 62: 193-201. http://dx.doi.org/10.3989/scimar.1998.62n3193

Castriota L., Scarabello M.P., Finoia M.G., et al. 2005a. Food and feeding habits of pearly razorfish, Xyrichtys novacula (Linnaeus, 1758), in the southern Tyrrhenian Sea: Variation by sex and size. Environ. Biol. Fish. 72: 123-133. http://dx.doi.org/10.1007/s10641-004-6576-0

Castriota L., Finoia M.G., Andaloro F. 2005b. Trophic interactions between Xyrichtys novacula (Labridae) and juvenile Pagrus pagrus (Sparidae) in the central Mediterranean Sea. Electron. J. Ichthyol. 2: 54-60.

Castriota L., Falautano M., Finoia M.G., et al. 2010. Temporal variations in the diet of pearly razorfish Xyrichtys novacula (Osteichthyes: Labridae). J. Fish Biol. 76: 1626-1639. http://dx.doi.org/10.1111/j.1095-8649.2010.02599.x

Espino F. 2004. Una metodología para el estudio de las fanerógamas marinas en Canarias. Rev. Acad. Canar. Cienc. 15: 237-256.

Espino F., Tuya F., Brito A., et al. 2011a. Ichthyofauna associated with Cymodocea nodosa meadows in the Canarian Archipelago (central eastern Atlantic): Community structure and nursery function. Cienc. Mar. 37: 157-174 http://dx.doi.org/10.7773/cm.v37i2.1720

Espino F., Tuya F., Brito A., et al. 2011b. Spatial variability in the structure of the ichthyofauna associated with Cymodocea nodosa seagrass meadows across the Canary Islands, north-eastern subtropical Atlantic. Rev. Biol. Mar. Oceanogr. 46: 391-403. http://dx.doi.org/10.4067/S0718-19572011000300009

Espino F., González J.A., Haroun R., et al. 2015. Abundance and biomass of the parrotfish Sparisoma cretense in seagrass meadows: temporal and spatial differences between seagrass interiors and seagrass adjacent to reefs. Environ. Biol. Fish. 98: 121-133. http://dx.doi.org/10.1007/s10641-014-0241-z

Ferrell J.D., Bell J.D. 1991. Differences among assemblages of fish associated with Zostera capricorni and bare sand over a large spatial scale. Mar. Ecol. Prog. Ser. 72: 15-24 http://dx.doi.org/10.3354/meps072015

Fischer W., Bauchot M.L., Schneider M. 1987. Fiches FAO d'identification des espèces pour les besoins de la pêche. (Rév. 1). Méditerranée et Mer Noire. Zone de Pêche 37. Vertébrés, Vol. 2. FAO. Rome. p. 1152
Franco A., Pérez-Ruzafa A., Drouineau H., et al. 2012. Assessment of fish assemblages in coastal lagoon habitats: Effect of sampling gear method. Estuar. Coast. Shelf Sci. 112: 115-125. http://dx.doi.org/10.1016/j.ecss.2011.08.015

Franquet F., Brito A. 1995. Especies de interés pesquero de Canarias. Consejería de Pesca y Transportes del Gobierno de Canarias, Santa Cruz de Tenerife, $143 \mathrm{pp}$

Froese R., Pauly D. (eds). 2015. FishBase. World Wide Web electronic publication. www fishbase.org, February 2015.

González-Ortiz V., Alcazar P., Vergara J.J., et al. 2014. Effects of two antagonistic ecosystem engineers on infaunal diversity. Estuar. Coast. Shelf Sci. 139: 20-26. http://dx.doi.org/10.1016/j.ecss.2013.12.015

Goshima S., Peterson C.H. 2012. Both below- and aboveground shoalgrass structure influence whelk predation on hard clams. Mar. Ecol. Prog. Ser. 451: 75-92. http://dx.doi.org/10.3354/meps09587

Gratwicke B., Speight M.R. 2005. The relationship between fish species richness, abundance and habitat complexity in a range of shallow tropical marine habitats. J. Fish Biol. 66: 650-667. http://dx.doi.org/10.1111/j.0022-1112.2005.00629.x

Gray C.A., McElligott D.J., Chick R.C. 1996. Intra- and inter-estuary differences in assemblages of fishes associated with shallow seagrass and bare sand. Mar. Freshw. Res. 47: 723-735. http://dx.doi.org/10.1071/MF9960723

Guidetti P. 2000. Differences among fish assemblages associated with nearshore Posidonia oceanica seagrass beds, rocky-algal reefs and unvegetated sand habitats in the Adriatic Sea. Estuar. Coast. Shelf Sci. 50: 515-529. http://dx.doi.org/10.1006/ecss.1999.0584

Guidetti P., Bussotti S. 2002. Effects of seagrass canopy removal on fish in shallow Mediterranean seagrass (Cymodocea nodosa and Zostera noltii) meadows: a local-scale approach. Mar. Biol. 140: 445-453. http://dx.doi.org/10.1007/s00227-001-0725-1

Guidetti P., Lorenti M., Buia M.C., et al. 2002. Temporal dynamics and biomass partitioning in three Adriatic seagrass species: Posidonia oceanica, Cymodocea nodosa, Zostera marina. Mar. Ecol. 23: 51-67. http://dx.doi.org/10.1046/j.1439-0485.2002.02722.x

Gullström M., Bodin M., Nilsson P.G., et al. 2008. Seagrass structural complexity and landscape configuration as determinants of tropical fish assemblage composition. Mar. Ecol. Prog. Ser. 363: 241-255. http://dx.doi.org/10.3354/meps07427

Hensgen G.M., Holt G.J., Holt S.A., et al. 2014. Landscape pattern influences nekton diversity and abundance in seagrass meadows. Mar. Ecol. Prog. Ser. 507: 139-152 http://dx.doi.org/10.3354/meps 10818

Herrera A., Landeira J.M., Tuya F., et al. 2014. Seasonal variability of suprabenthic crustaceans associated with Cymodocea nodosa seagrass meadows off Gran Canaria (eastern Atlantic). Cont. Shelf Res. 88: 1-10. http://dx.doi.org/10.1016/j.csr.2014.06.014

Hori M., Suzuki T., Monthum Y., et al. 2009. High seagrass diversity and canopy-height increased associated fish diversity and abundance. Mar. Biol. 156: 1447-1458. http://dx.doi.org/10.1007/s00227-009-1184-3

Horinouchi M. 2009. Horizontal gradient in fish assemblages structures in and around seagrass habitat: some implications for seagrass habitat conservation. Ichthyol. Res. 56: 109-125. http://dx.doi.org/10.1007/s10228-008-0070-1

Katsanevakis S. 2005. Habitat use by the pearly razorfish, Xyrichtys novacula (Pisces: Labridae). Sci. Mar. 69: 223-229.

Lieske E., Myers R. 1994. Collins pocket guide. Coral Reef Fishes. Indo-Pacific and Caribbean including the Red Sea. Harper Collins, New York, $400 \mathrm{pp}$.

Marconato A., Tessari V., Marin G. 1995. The mating system of Xyrichthys novacula: Sperm economy and fertilization success. J. Fish Biol. 47: 292-301. http://dx.doi.org/10.1111/j.1095-8649.1995.tb01896.x

Mercader L. 1991. External morphology of the juveniles of Xyrichthys novacula (Linnaeus, 1758) (Pisces, Labridae) from the littoral of Palamós (NW Mediterranean). Misc. Zool. 15: 243-246.

Ministerio de Medio Ambiente. 2002. Estudio Ecocartográfico del Arco Sur de la isla de Gran Canaria. Gobierno de España. Madrid.

Navarro-Pérez E., Barton E.D. 2001. Seasonal and interannual variability of the Canary Current. Sci. Mar. 65: 205-213.

Nemtzov S.C. 1994. Intraspecific variation in sand-diving and pred- 
ator avoidance behavior of green razorfish, Xyrichtys splendens (Pisces, Labridae): effect on courtship and mating success. Environ. Biol. Fish. 41: 403-414. http://dx.doi.org/10.1007/BF02197856

Oliver M., Massutí M. 1952. El raó, Xyrichthys novacula (Fam. Labridae). Notas biológicas y biométricas. Bol. Inst. Esp. Oceanogr. 45: 1-15.

Peterson C.H. 1982. Clam predation by whelks (Busycon spp.): Experimental tests of the importance of prey size, prey density, and seagrass cover. Mar. Biol. 66: 159-170. http://dx.doi.org/10.1007/BF00397189

Riera F., Linde M. 2001. El raor, Xyrichthys novacula (Linnaeus, 1758). In: El raor i la cirviola. Conèixer per preservar. Govern de les Illes Balears, Conselleria d'Agricultura i Pesca. Quaderns de Pesca 6: 9-34.

Sachs L. 1982. Applied Statistics: A Handbook of Techniques. Springer-Verlag, New York, 706 pp. http://dx.doi.org/10.1007/978-1-4684-0123-3

Schneider W. 1990. FAO Species Identification Guide for Fishery Purposes. Field Guide to the Commercial Marine Resources of the Gulf of Guinea. FAO, Rome, 268 pp.

Sokal R.R., Rohlf F.J. 2012. Biometry: The Principles and Practice of Statistics in Biological Research. 4th Edition. W.H. Freeman and Company, New York, 937 pp.

Tuya F., Pérez J., Medina L., et al. 2001. Seasonal variation of the macrofauna from three seagrass meadows of Cymodocea nodosa off Gran Canaria (Central-Eastern Atlantic Ocean). Cienc. Mar. 27: 223-234.

Tuya F., Boyra A., Sánchez-Jerez P., et al. 2004. Relationships between rocky-reef fish assemblages, the sea urchin Diadema an- tillarum and macroalgae throughout the Canarian Archipelago. Mar. Ecol. Prog. Ser. 278: 157-169. http://dx.doi.org/10.3354/meps278157

Tuya F., Boyra A., Sánchez-Jerez P., et al. 2005. Multivariate analysis of the bentho-demersal ichthyofauna along soft bottoms of the Eastern Atlantic: comparison between unvegetated substrates, seagrass meadows and sandy bottoms beneath sea-cage fish farms. Mar. Biol. 147: 1229-1237. http://dx.doi.org/10.1007/s00227-005-0018-1

Tuya F., Martín J.A., Luque A. 2006. Seasonal cycle of a Cymodocea nodosa seagrass meadow and of the associated ichthyofauna at Playa Dorada (Lanzarote, Canary Islands, eastern Atlantic). Cienc. Mar. 32: 695-704.

Tuya F., Wernberg T., Thomsen M.S. 2011. The relative influence of local to regional drivers of variation in reef fishes. J. Fish Biol. 79: 217-234 http://dx.doi.org/10.1111/j.1095-8649.2011.03015.x

Tuya F., Ribeiro-Leite L., Arto-Cuesta N., et al. 2014a. Decadal changes in the structure of Cymodocea nodosa seagrass meadows: Natural vs. human influences. Estuar. Coast. Shelf Sci. 137: 41-49. http://dx.doi.org/10.1016/j.ecss.2013.11.026

Tuya F., Png-González L., Riera R., et al. 2014b. Ecological structure and function differs between habitats dominated by seagrasses and green seaweeds. Mar. Environ. Res. 98: 1-13. http://dx.doi.org/10.1016/j.marenvres.2014.03.015

Underwood A.J. 1997. Experiments in ecology. Their logical design and interpretation using analysis of variance. Cambridge University Press, 504 pp. 